\title{
Attracting Foreign Direct Investment in Developing Countries: Determinants and Policies-A Comparative Study between Mozambique and China
}

\author{
Paulo Elicha Tembe (Corresponding author) \\ Economics \& International Business, School of Economics \& Management \\ Southeast University, No. 2 Sipailou, Nanjing 210096, China \\ E-mail: Paulo_tembe@yahoo.com.br \\ Kangning $\mathrm{Xu}$ \\ Professor, Dean of School of Economics \& Management, Southeast University \\ E-mail: xkn@seu.edu.cn
}

Received: August 13, 2012

doi:10.5430/ijfr.v3n4p69
Accepted: September 17, 2012

Online Published: October 12, 2012

\begin{abstract}
Attraction of foreign direct investments has been deserving attention for many governments worldwide. Using different literature about Foreign Direct Investment, this paper analyzes the determinants and policies to attract foreign direct investments to developing countries and makes a comparative study between Mozambique and China. The results found, indicate the difference among countries in attracting investments due to their different geographic location, conditions of infrastructure (poor or developed), corruption, taxes as well as the implementation of the policies by the governments. These results also show that successful policies in China should not be copied or implemented by Mozambique. Foreign Direct Investment must only be allowed to operate according to local conditions and must conform to certain performance requirements that will ensure a positive impact on development. Evidence within this paper shows that Africa is different in attracting FDI due to the lack of high return on capital and infrastructure development, and openness to trade.
\end{abstract}

Keywords: FDI, Developing countries, Determinants, Policies, A comparative study

\section{Introduction}

Recently the whole world has been witnessing a dramatic increase in foreign direct investment to developing countries with Foreign Direct Investment increasing from \$24 billion (24\% of total foreign investment) in 1990 to $\$ 178$ billion in 2000 (World Bank, 2001) quoted by Asiedu (2002). The role of Foreign Direct Investment as a source of capital has become increasingly important to African countries. Therefore, income levels and domestic savings in the region are very low. According to Asiedu, external capital is needed to supplement domestic savings in order to spur investments and growth. Official lending to the region has declined from 6\% in 1990 to $3.8 \%$ in 1998.

Foreign aid per capita declined from an average of 35\$ over 1989 -92 to about \$28 over 1993 - 97. Nevertheless, as presented by above quote, during $1980-84$ and $1994-97$, the annual average of FDI to developing countries increased by $1,630 \%$, while FDI to Africa increased by $496 \%$ and as a result, Africa's share in total FDI flows dropped significantly from $36 \%$ in 1970 - 74 to $10 \% 1980$ - 84 and to 3\% in $1995-99$.

Mozambique plays a strategic position related to the choice of many foreign countries that aim to get started with business in Africa. There are a growing number of multinational companies aiming to develop their business in Mozambique. So far, this southern African country has a good bilateral relationship with China which started decades ago and as a coincidence or not, China was the very first country investing heavily either in education, political or economic issues. Strategies and policies will play an important role in attracting investment to many developing countries especially to Mozambique. 
One of the main objectives of this paper is to work on why there is a great difference among developing countries in attracting FDI with focus in the country in analysis. Using data of different research on this issue, this paper will look for the determinants of FDI to developing countries and suggests the strategies and policies that may have a positive impact in promoting economic growth in Mozambique.

On the other hand this paper will make a comparison between China and Mozambique in terms of attracting FDI to see what Mozambique can learn from China and make some policy suggestions.

Sun et al (2002) state that China has attracted a spectacular amount of FDI since its opening to the outside world in 1979 that jumps from virtual zero in this period to an amount of US\$45.46 billion in 1998. China development has seen three different stages: First stage starts from 1979 with the presence of Joint Ventures and Foreign Investment. The setting up of special economic zones -Shenzhen, Zhuhai, Xiamen, and Shantou in 1980. The year of 1984 that China opened 14 more coastal cities and Hanan Island to foreign investment. The Pearl River Delta, the Yangtze River Delta, and the Zhangzhou-Quanzhou-Xiamen region were created three years later.

This open policy that took place three decades ago in China, as well as cheap labor force helped the country to attract FDI and have a rapid development in its economy and infrastructures.

Mozambique introduced an Economic Recovery Program (ERP) supported by the International Monetary Fund (IMF) in 1987. Pretorius and Nordas (2000) argue that the basic elements of the program were stabilization of economy, privatization and reforms with regard to liberalization of external and internal trade. They indicate that the ERP program was not successful because there were no such defined special zones and areas to develop economy in a long run and the investments were mainly allocated in primary industries. Analyzing the points of the above quote we can conclude that this kind of positive experience of Chinese government in developing economy by opening special economic zones can be learned by Mozambican government. However, policies and strategies that were successful in China may not be successful in Mozambique, because these two countries differ in many aspects such as geographic location, culture and political background. The strategies regarding development must occur in accordance with the country economic condition not in the same rhythm.

This research paper will specifically review the policies taken by governments of China and Mozambique to attract FDI by analyzing the root of China's success and comparing the policies of Chinese government to those of Mozambican government.

The present paper will be divided into 6 sections: The first part is reserved for introduction; second is a brief introduction to FDI in developing countries; third is literature review discussing many theories related with foreign direct investments from different perspectives. The fourth section will summarize the determinants of FDI as well as trying to answer the question why African countries are different in attracting investments; the fifth part is a comparative study between China and Mozambique presenting the reasons why Mozambique fails to attract a considerable number of FDI. Basically in this chapter were made some interview with Mozambican government in order to explore the possible reasons that are beyond the failure of this country in attracting considerable investments and finally the conclusion.

\section{The State of FDI in Developing Countries}

FDI has expanded strongly over the past three decades. The growth in FDI accelerated in the 1990s, rising to \$331 billion in 1995 and \$1.3 trillion in 2000 UNCTAD (2002). As a result, developing countries experienced a sharp increase in the average ratio of FDI to total investment during the 1990s. Therefore, in this region FDI in services increased at an annual rate of $28 \%$ over the period of 1988 to 1999 , and accounted for $37 \%$ of total foreign investment inflows one decade later.

The above quote organization states that in developing countries, an essential requirement for economic growth and sustainable development is the provision of efficient, reliable and affordable infrastructure services such as water and sanitation, power transport and telecommunication. But since some developing countries like African the investments are driven by natural resources, the infrastructure can be built in partnership with the investors as exchange of low taxation.

The region of Latin America and the Caribbean, inward foreign direct investment (FDI) reached US\$ 72.4 billion in 2006 up from US\$ 71.4 billion in 2005 and US\$ 66 billion in 2004. Historically Latin America and Caribbean received a larger share of global FDI inflows than it does now. The 1970s, the amount of FDI inflows received by developing countries was larger at about $40 \%$ to $50 \%$ but in 2006 has fallen to approximately one-half its former level. 
The analysis conducted by the Economic Commission for Latin America and the Caribbean ECLAC (2006) combines two data sets to examine the nature of FDI and the presence of TNCs in the region. The first consists of balance of payments information on FDI inflows and outflows; the second set relies on information on the operations and transactions of individual companies. In economic point of view, this data set examination of this organization seems to measure the scope of capital flows in the region with the presence of competitive companies.

In turn, African countries are keen on attracting FDI and the presence of considerable amount of foreign investments are the key to solving Africa's economic problems. However, African countries design and implement policies, build institutions and sign investment agreements to attract investments.

Mwilima (2003) states that the main five reasons governments of Southern Africa want to attract FDI is just because they see FDI as an important source of capital formation; the second reason is the transferring of technology; another reason is argued that FDI will lead to employment creation; the reason number four, the government expect FDI to transfer management skills to local managers and the last one is the increase of export competitiveness.

Even though African governments try to enable environment to attract more FDI as mentioned above, Mwilima says that Africa will continue not gaining so much from the investments just because when most of the African countries open their markets as kind of incentive to promote development, the investors move to these countries for different reason. This point of Mwilima can be reverted if the host and guest country of FDI combine their interests which will lead to a win-win situation enabled by controlling the taxation and capital flows.

Different from Africa and Latin America, Asian markets continue to be major destinations of international capital flows, both in terms of security investments and foreign direct investments. More than $40 \%$ of total capital flows to emerging markets is estimated to be directed towards Asian markets. According to CGFS (2003), Asian markets have grown considerably with an amount of \$23 billion by 1998 but the overall amount and growth were much smaller than in Latin America. As confirmed by Rabin and Rajan (2009) the landing investors from the region have stayed the same from 1997 to 2006, with Hong Kong as the top investor followed by Singapore, Taiwan, Korea, China and Malaysia. Intra-Southeast Asia investment accounted for 6.7 percent of cumulative FDI flows in Asia between 1997 and 2005.

Despite the calling of attention of these emerging countries in terms of attracting FDI, eastern region including countries like Czech Republic, Hungary, Poland and Slovakia together with Estonia, Lithuania and Slovenia, is now regarded as the second most attractive foreign investment locale after Western Europe and is the most favored place for investments in the manufacturing industry. On the other hand, OECD states that between 2000 and 2004 the Central and Eastern Europe (CEEs) share of total inward European FDI increased from 17\% to 31\%, reaching a total of USD 18.8 billion in 2004.

\subsection{The Impact of FDI on Developing Countries}

Foreign Direct investment has cost and benefits. The benefits and risks will only lead to economic growth in the host country under certain conditions such as political and macroeconomic environment. Mwilima (2003) states that the impact of FDI in a country would depend on a number of factors such as: the mode of entry; the sources of finance for FDI; the impact on the activities of domestic companies.

Some critics mention that FDI can bring benefits but also can bring negative impact. For example: The activities of MNEs can cause large scale environmental damage especially in the mining sector. But many research works have shown that the contribution of FDI to growth is positive. FDI inflow to the manufacturing sector has a positive effect on growth directly by creating employment opportunities and indirectly through the creation of employment opportunities.

\section{Literature Review}

Moosa et al. (2005) consider the fact that FDI has several facets but the policy makers in capital-starved countries are concerned with the determinant of FDI inflows. Governments have stronger policy incentives for foreigner investors who are potentially capable of providing FDI flows and these Policies to attract FDI have become standard in most countries. For Bellak (2008), one of the most important policy question presented by these authors is what should be done in order to attract inward FDI in terms of which policy variable to be used to attract FDI in general. But Bellak et al also suggest that another related question is how large is the scope for FDI in general and in certain industries in particular.

The majority of developing countries have adopted measures of liberalizing the framework for FDI and implemented mechanisms for the settlement of investment disputes to attract FDI in order to promote development. Lim (2007) 
analyzes this perspective and argues that governments play an important role in attracting investments to countries, by promoting open policies, and implementing strategies that invite foreign companies to get started with business since the conditions created by governments are favorable. Some studies suggest that national strategic marketing management is needed to create or increase economic development where the government can market a country in the same way as a company's products and services in order to attract foreign direct investment. This kind of strategy to market the country as a company will be discussed in subsequent chapters specifically the type of strategy designed by Mozambique government to attract FDI. There is no uniform determinant to attract FDI. The lack of consensus is due to the huge differences in perspective, methodologies, sample collection and analytical tools. But yet one of the most important traditional FDI determinants is the size of national market and natural resources. The economic determinants related to large markets, trade barriers and non-tradable services are still being considered as a large share of worldwide FDI flows. Therefore, the same traditional determinants mentioned above can be divided into sectors such as economic and financial where market size is crucial to enable competitiveness as well as enabling very well designed clear and stable policies by host country to attract foreign direct investment.

\section{Why Are African Countries Different}

Asiedu (2002) uses an empirical analysis which employs a more comprehensive dataset including 71 developing countries about half of which are SSA countries and 39 non-SSA countries. For him, analyzing FDI flows to Africa is important for several reasons: First, on the subject of FDI, Africa remains under researched without any study that exclusively focuses on Africa; The second reason he indicates is that having into account that FDI contributes to growth, it is important to know the factors that affect FDI flows to the slowest growth region, Africa; Third, FDI to SSA is driven by different factors. These empirical findings by Asiedu are combined within this paper by suggesting that Mozambican government must not copy policies which were successful in China to implement them in the country without paying attention to local economic and geographic conditions

Therefore, Asiedu (2002), summarized the results found by stating that (i) countries in SSA have received less FDI than countries in other regions due to their geographical location; (ii) Higher return on capital and infrastructure development; (iii) Openness to trade. So, these results shown above suggest that Africa is different. On the other hand Goodspeed et al (2006), in their study with regression results, state that lower taxes, lower corruption, and better infrastructure attract FDI. The fact that African countries face all these problems stated above they will remain different comparatively to other regions.

The literature discussing the attraction of FDI and its opinions converge when the point is Africa. also the lack of credibility, the change in bargaining power and the failure to protect and enforce property rights indicated by Kebonang and Mosweu, (2004) may be a hypothesis scaring investors of making long term commitments in Africa.

\section{A Summary of the Determinants of FDI}

There is no consensus on the determinants of FDI but, one of the most important determinants of foreign direct investment is the size of the market as indicate in the above chapter as well as the growth prospects of the economy of the country where the foreign direct investment is being made. Normally countries with big market can grow quickly from an economic point of view and it is concluded that the investors would be able to make the most of their investments in those countries.

Foreign Direct Investments that are based on export, the dimensions of the host country are important as there are opportunities for bigger economies of scale, as well as spill-over effects. The number of population plays an important role in attracting foreign direct investment to a country.

The differences on the determinants of FDI for both developed and developing countries are shown on the results of Azemar and Delios (2007). In their study they mention that taxes play a significant role in the location of FDI in developing countries even when determinants related to imperfect competition are controlled for in the estimation. On the other hand, Wei and Ali (2005) state for example that China's potentially huge domestic market is the major determinant of its inward FDI from OECD countries, contrarily in India where both domestic market and cheap labor cost are important determinants of its inward FDI from OECD countries. Yet both policy and non-policy factors can be considered as drivers of foreign direct investment.

\section{A Comparison between China and Mozambique}

\subsection{The State of FDI in China}

FDI in China has gone through various phases. The peak period was the 1990s, different from the moderate growth in the 1980s, the period called by growth development. Many researchers argue that although a lot of interests among 
foreign investors in China emerged after 1979, large FDI inflows did not occur in the initial period because of the poor infrastructures. The period of 1983 - 1991 saw a steady growth and relatively large inflows. The special economic zones expanded from four to fourteen cities and FDI incentives introduced in 1986. China's peak was US\$110.852 billion in 1993 and became the largest host country for FDI among the developing countries and the second large host country in the world.

Equity Joint Ventures (EJVs), Contractual Joint Ventures (CJVs) and the establishment of wholly foreign owned enterprises (WFOEs) was the main entrance mode in China. Contractual Joint Ventures were initially the most important type since 1980s. Equity Joint Ventures and wholly foreign owned enterprises became predominant and in recently China boomed with wholly foreign owned enterprises.

In turn, equity Joint Ventures has been a popular entry mode for two reasons. The first serve the Chinese objective of foreign capital, technology and management experiences; the second reason is that foreign investors hope through engaging in joint ventures to get local partner’s assistance in the domestic markets (See Chart 1).

Despite of the rapid growth of China's FDI in recent years, its share of the world's total FDI remained very small. The period of 2002 and 2003 was the period which Chinese flows of FDI accounted for a minuscule 0.5\%, but it was tripled to $1.57 \%$ in 2005 .

The chart represents only the state of FDI in China from five years after setting new regulations to permit joint ventures using foreign capital and setting up special economic zones (SEZs) and open cities. This data represent the 90's which was the peek period of FDI. However the purpose of selected data was made in order to give an overall picture of FDI since the release of regulation to attract Foreign Direct Investment in china till its stabilization. But as the title is about the state of FDI in China this paper will give a current situation of FDI state based on data released by Ministry of Commerce People's Republic of China. The figures give us a current situation of inward FDI within mainland China. The data released by Ministry of Commerce People’s Republic of China, indicate that from January to June 2012, newly approved foreign-invested enterprises amounted to 11,705 , down by $13.05 \%$ year on year; and the actual use of foreign investment reached US $\$ 59.089$ billion, down by $2.96 \%$ accordingly. As shown in the figure the number of foreign companies tend to grow and promote stead growth on the Chinese economy (See Chart 2).

The statistics of news release of foreign investment, in June 2012 show that enterprises amounted to 2,444, down by $16.27 \%$ year on year; and the actual use of foreign investment reached US\$11.979 billion, down by 6.87\%. (See Chart 3) According to the Chinese government site on FDI, the period of January to June, 2012, the number of newly established enterprises funded by ten Asian countries as the following: (Hong Kong, Macao, Taiwan, Japan, the Philippines, Thailand, Malaysia, Singapore, Indonesia, ROK) was 9,169, down by $15.49 \%$. The recent input pictures were US $\$ 51.067$ billion, down by $2.79 \%$ year on year. The number of enterprises funded by US was 698 , down by $3.99 \%$. Recent indicators were US\$1.625 billion, down by 3.2\% year on year. In turn, for EU funded enterprises the picture was 848 up by $0.95 \%$ with actual input of US $\$ 3.518$ billion up by $1.56 \%$ accordingly.

\subsection{Policies Taken by Chinese Government to Attract FDI}

One of the most key elements of China's economic reform process has been the encouragement of foreign direct investment. Since late 1970 as mentioned in the chapter above, China has gradually opened its economy for foreign businesses and has attracted large amount of foreign direct investment. China's policies toward FDI have also experienced various changes on their policy priorities. .The decision to open up China to the world economy was formally included in the state constitution adopted by the Six National People’s Congress. Fung et al (2002)

From 1984, the extension to another fourteen coastal cities, twelve of them were designated Technology Promotion Zones one year later to expedite the transfer of technology. In 1990, the Pudong district of Shanghai was designated as a new development zone to lead development along Yangtze River.

The success of these policies are confirmed by Tseng and Zebregs (2002) arguing that the investors were also allowed to undertake their own infrastructures development and other investment as long as they could raise the funds from taxation, from profits of the enterprises they own wholly or partly or from banks in the zones.

Even though China has been so successful in policies to attracting FDI, the efforts to maintain the interesting in China are still made by the government. This is proved by Zhou (2008) stating that measures to promote Chinese FDI are indicated in the Giving Credit Support to the Key Overseas Investment projects encouraged by the State issued by the National Development and Reform Commission and the Export-import Bank of China in October of 2004. 
In fact, looking at the policies taken by Chinese government to attract FDI, we can state that China will still be the only country in the world which will always call attention of many investors to visit it in order develop their business.

\subsection{The State of FDI in Mozambique}

Mozambique has a strategic geographic location with extensive coastal line. It is located in the Southern Africa. Mozambique shares a logistical and commercial trade platform with countries such as Zambia, Zimbabwe, Malawi, South Africa, Swaziland, Tanzania and Botswana. Links with South Africa, the region's largest economy, is a great potential to develop Maputo corridor, the capital of Mozambique. The freight transport system in Mozambique is based on 3 rail port system with estimated transaction volumes like Southern line with reference to the port of Maputo connecting Zimbabwe and Swaziland. The second rail port system is located in Beira corridor which is again rebounding thanks to new projects in coal extraction in Tete province. Another line is southern which serves the port of Nacala, carrying less than one million tones a year, but another project to allow the port to carry more than 30 million tones in on the way.

Therefore, sectors like Tourism, Agro-Industry, Agriculture equipment, Techniques and Construction are the sectors where investments are conducted, as it is shown in the figure. (See Figure 1)

FDI entries in Mozambique increased by 37.4\% in 2008 reaching USD 587 million. The contribution of major projects is being reduced representing approximately 50\% of total FDI. (See Chart 4) According to Reserve Bank of Mozambique (2009), Mozambique received many investments in the year of 2008 from different countries where South Africa contributed with a huge number of investments (see Chart 5).

\subsection{Why Mozambique Fails to Attract a Considerable Amount of FDI?}

The country has a vast energy resources both in terms of hydropower, natural gas and metallurgical coal.The Cahora Bassa dam on the Zambezi River is among the largest hydropower plants in Africa with a production capacity by far exceeding local demand. In addition, the country has a rich natural gas field. There are four recent large multinational projects. One of the largest foreign investment projects is a South African/Japanese aluminum smelter which was established in 1998 having a total annual production of around 530.000 tones, which benefits from supply of low cost electricity. The second large project is a Brazilian multinational called Vale exploring metallurgical coal in Tete, a central province of Mozambique, and the third is Australian multinational called Rio Tinto exploring also coal in the north part of the country. The fourth and last to be established is an Italian company called Eni Mozambique exploring oil and Gas. Mozambique is also rich in fertile land, fisheries and has a long coastline suitable for tourism. The country has thus received a number of foreign investments in agriculture, food processing and hotels. Agriculture has received last year, 2011 a Brazilian project called Prosavana. With an exception of agriculture this corresponds a current figure of FDI forced by the discovery of natural resources in less than 5 years.

One important factor for attracting this small number of foreign investments has been investment in infrastructure which was very small. During the civil war the transit routes were totally destroyed, but rehabilitation has been a priority during the reconstruction of the country. South Africa has helped the country to rebuild infrastructures, and an industrial development zone where investors enjoy investment incentives and exemptions from import duties has been established in the corridor. The second largest transport corridor, the Beira corridor runs from the Beira harbor to Harare. It has attracted FDI in labor intensive industries, mainly from Mauritius. Kind et al (2001).

Therefore, the geographical position that Mozambique enjoys with some African countries in terms of its corridors, allowed the country to create in the year of 1999 a decree No. 62 of 21 September of industrial free zones. The decree and the article of investment law $3 / 93$ of the $24^{\text {th }}$ June, define an IFZ - industrial free zones as a legal entity that is export-oriented and designed to enhance industrialization, Geraldo (2007). Mozambique has two different types of zones. It has industrial parks which has small projects and mega projects located outside the industrial parks.

The reason why these industrial free zones where not successful in attracting more FDI are beyond the evidences shown by Goodspeed et al (2006) in their study from which concluded that lower taxes, lower corruption, lower government consumption spending and better infrastructure should attract FDI. In fact, is so premature not to mention facts presented by Goodspeed et al due to high rates of corruption in Mozambique with taxes that are considerably high and government consumption spending which also remains high. Although Geraldo (2007) focuses on the effort of Mozambican government in reconstructing infrastructures by the period after the civil war, it is important to mention that the reconstruction was specifically for what was destroyed not exactly for new ones with a modern design that could fit the demand of the investors. 
The failure of this country in attracting more FDI was surely due to the lack of quality infrastructure. On the other hand, was just because the country by that period was coming from a political instability where the investors were in doubt on whether the peace was forever or not. But twenty two years of peace have already passed and the figures for investments remain small. Another reason is that Mozambique had only defined two special economic zones where the principal one is Maputo corridor, linking Mozambique to South Africa and Swaziland and it is located in the capital and, another is Nacala port for fuel production, agriculture and tourism. Nacala economic zone was formally created in December 2007, eight years after the decree was released even with its strong potential. However, for a country with eleven provinces, there were only two zones regarded as special zones to promote development for the rest of the country. This development occurred partially in a small part of the Southside of the country, contrarily of China that jumped from four into fourteen zones that brought a very positive development. Twelve of the fourteen cities were designated Technology Promotion Zones and later on, Shanghai was designated new development zone. There were interesting phases in China that contributed to development which is totally different to Mozambique. This is a lesson to be learned from this successful country. Recently, Mozambique government has created other three economic zones not conditioned by the presence of natural resources. The hypothesis of the creation of such economic zones might be to avoid disparity in development.

As argued by Tseng and Zebregs (2002), there are also some pitfalls in China's FDI experience that provides lessons to other countries. In particular, by having focused on specific regions which led to the growing income disparity between the coastal and inland provinces. More increased investments and infrastructure creation allowed China to reduce the discrepancies. Furthermore, in their study they raise a question about what factors are most important in attracting FDI. However, they conclude that to answer this question might be a comparison on the magnitude of changes in taxes, corruption and infrastructure.

From a policy perspective seems that the right approach by governments related with attracting foreign direct investment is to lower corruption and to keep taxes low and to maintain investment in infrastructure rather than using revenue for consumption expenditures. The above point of view agrees with Goodspeed et al (2006) in affirming that keeping public revenues too low to adequately maintain or invest in infrastructure is unlikely to be a successful long run policy.

One of the other reasons why Mozambique fails to attract a considerable FDI, as published by African Trade Policy Centre (2005), discussed in chapter 4 can be beyond the poor and ineffective marketing strategy where African governments set up agencies to promote foreign investment without taking adequate steps. It seems that this statement of the Trade Policy Centre proves that in fact IPA in Mozambique was created in a premature time before any experience achieved from those who have succeeded even from China that was number one political and economics partner to Mozambique. To give a real picture of the above point, was created recently in Maputo province an industrial park of Beleluane for transferring technology and know-how of Chinese experience. Thirteen years after the decree was released. This drives us to conclude that before the creation of the decree No. 62 of 21 September of industrial free zones was not made any kind of research for possible accommodation of industrial park especially for technology transfer and know-how.

\subsection{Policy Implications to Mozambican Government}

On the view of Fujita (2007), Policy makers and researchers require data classified by economic activity and geographical location to understand full the impact of FDI at both the macro and micro levels. Governments must evaluate the amount and kind of FDI according to development objectives.

According to Pretorius (2000) Mozambique has the two laws that directly regulate national and foreign private investments approved on 24 June 1993 and the regulation of investment law (No 14/93), approved on 21 July 1993 with changes approved by decree No. 36/95.

The law on investment highlights the government of Mozambique objectives for establishing laws and attracting investments to promote development and economic growth. These laws treat both foreign and domestic investors equally by giving protection and guarantee of investments.

On the view of many researchers, the best way of attracting FDI and drawing more benefits from it, is not passive liberalization alone. Governments have to create policies and strategies that go together with liberalization to make accessible to all economic agents. Attracting types of FDI with greater potential for benefiting host countries is necessary. The challenge for developing countries like Mozambique is to design and implement a development-oriented balance which will lead to economic growth in a long run. 
The main determinants in Mozambique are the access to resources and a non restrictive investment as well as tax concessions. Although some researchers highlight the fact that Mozambican government focused its strength in rebuilding infrastructures destroyed during the civil war, there is a kind of ambiguous ideas if we look at what is argued by them in mentioning that, the rehabilitation of infrastructure was to promote development. In fact, economic rehabilitation program - ERP was a fact in that period and, was not to seek for foreign investments but to replace destroyed infrastructures through foreign aid. However, there is a lesson that can be learned from China related to strategies used to attract foreign investments because by that time although China had a huge market, investments did not occur due to the existence of poor infrastructures.

Therefore, China has focused its effort in modernizing infrastructures to attract more foreign investments. The year of 1991, saw a steady growth and large inflows. The special economic zones expanded from four to fourteen cities. Chinese government betted on foreign Joint Ventures because believed that with this kind of entry mode would contribute to the transferring of technology. This is something which was totally different for Mozambican government who asked for aid not for the modernization of the country but to recover the gape left by the war.

There was a very big difference between China and Mozambique in terms of policies to attract FDI, and the number of regions developed by foreign investments. Pretorius (2005) confirms the disparity, for example in geographical and provincial contribution to the Mozambican national GDP, the northern region contributed 21\%, while the central contributed $31.4 \%$ and the southern region contributed $47.6 \%$. The capital Maputo contributed alone $34.3 \%$ of the southern region's 47.6. At the level of provinces Maputo accounted with 34\% of the entire Mozambican GDP, followed by the province of Nampula with $13 \%$ and Sofala and Zambézia with $11 \%$ each. The remaining seven provinces contributed between $2 \%$ and $5 \%$. Recently these indicators are changing by the discovery of natural gas and metallurgical coal. It seems that Tete province and Rovuma Bay are on the track to the development forced by their natural resources and in turn, Nacala port that enjoys a strategic location in terms of transportation to some African countries and different continents has a considerable number of investors with interests in linking many countries of different regions at the same time.

These disparities in economic growth (GDP) among Mozambique’s industrial sectors in 1997 were found in services sector which contributed to GDP with $48.5 \%$, agriculture with $30.2 \%$ and industry with $17.4 \%$. The services sector is driven by commerce with $22.5 \%$ and the industry is driven by manufacturing and construction with $9.7 \%$ and $6.7 \%$ respectively.

In fact, strategies and policies to attract FDI in China and Mozambique were extremely different, although China also had disparity in terms of foreign investments distribution. As confirmed by Tseng and Zebregs (2002) by stating that FDI pattern in China shows a great disparity among regions. The eastern region accounted for 64\% of GDP while the central region was $29 \%$ and the western was $23 \%$. Chinese government has made experiments reforms in selected regions and sectors before extending them to other parts of the country.

These numbers above demonstrate the differences between China and Mozambique. Although by that time both countries had agriculture as the basis for the economy, investments were allocated in different sectors. Mozambique betted on subsistence agriculture and services with higher rates rather than other important sectors for development and, the majority of investments were concentrated in Maputo. However, differently from Mozambican government, China has allocated the investments in other places that were not regarded as special zones. Furthermore, foreign direct investments were allowed only in other cities different of the fourteen ones in order to eliminate inequality in infrastructure development.

China allocated the investments in secondary industry and on the development of infrastructures, and the failure of Mozambique to be like China was just because continued to consider agriculture and services as crucial for development. This is confirmed by Pretorius (2005) stating that Mozambican economy is agriculture-based with high levels of unemployment and poverty and low levels of economic growth, income, education and health care, to a modern industry economy. The country's poor performance is due to a lack of appropriate and effective institution such as Investment Promotion Centre (IPC) and a consequence of a lack of productive capital and inappropriate government policies. Mozambique government believes that productive investments will modernize and transform the country's economic institutions from agriculture to technology intensive manufacture-based industries to allow the export of goods.

The East Asian developing economies were transformed from being agriculture-based into dynamic, newly industrialized economies. This is an economic strategy that should be learned by African countries specially Mozambique in order to promote productivity and production. 


\section{Conclusion}

This paper has studied the determinants and policies for attracting FDI to developing countries as well as analyzing the differences among them in attracting investments to the region. African countries specially Mozambique has deserved attention within the discussion of this paper, due to its unsuccessful attraction of foreign investments despite the effort taken by the governments in implementing policy reforms.

Therefore, policies, strategies, development models that have been successful in China should not be copied or implemented to Mozambique because the impact may be harmful because the conditions are not both favorable and applicable in the same way. This paper is worthwhile because will help the governments of developing countries especially of Mozambique to define policies and strategies which better fit their own living style, culture and economic conditions.

The results achieved show that the difference among developing countries in terms of investments attraction, lies in geographical location of the countries and the level of infrastructure development, a situation that makes Africa as a destine of less investments. However, the determinants to attract more investments bring no common sense on which country can attract much FDI than another. On the other hand, the key factors determining the presence of FDI are host country market size, export orientation policy and FDI liberalization condition, the amount of natural resources and labor as well as the level of risk of investment both in terms of the economic and political environment. African countries will continue in a long period receiving less FDI if the number of population does not grow to allow a considerable size of the market.

Therefore, Mozambique has mainly allocated its investments effort on primary industries which did not contribute that much for the economy. Most of the investments contributed to indebt the country because they were mainly based in foreign aid, and some investments occurred as a kind of imposition of the investors, a situation that did not give any chances to the government to select priority areas. However, Chinese government did not proceed with the investments due to poor infrastructures, where allocated its efforts in building and modernization of the infrastructures. Certain regions of China were divided into parts: The special economic zones and later on, twelve of the fourteen cities were designated Technology Promotion Zones. The development of Infrastructures remain the very important thing to attract investment like happened in China, also equity Joint Ventures has been a popular entry mode in China, because of the belief that equity joint ventures best served the Chinese objective of foreign capital, technology and management experiences. This successful experience of Chinese government is something which deserves rigorous attention and a challenge for many unsuccessful governments especially to Mozambique. Yet this comparison study has been made respecting the steps taken by both governments having into account local strengths and weaknesses. Therefore, this paper gives a space to raise a question which calls attention on which development model is adequate to this southern country, Mozambique: Will Mozambique be a "copy paste” of Chinese policies and strategies or will look at those that identify the current situation and needs to the economic development of the country?

Finally this paper has many limitations of data due to the lack of specific literature related to Mozambique, and deserves further discussion for the improvement of subsequent papers willing to research on this topic.

\section{References}

Asiedu, E. (2002). On the determinants of foreign direct investment to developing countries: is Africa different? World development, 30(1), 107-119. Elsevier Science. University of Kansas, USA. http://dx.doi.org/10.1016/S0305-750X(01)00100-0

Azemar, C., \& Delios A. (2007, February). Tax Competition and FDI: The Special Case of Developing Countries. Journal of the Japanese and International Economies. Elsevier, ScienceDirect. Paris: France.

Bellak, C., \& et al. (2008, March 27-28). Policies to attract foreign direct investment: An industry-level analysis. Global forum on international investment. Vienna.

CGFS. (2003, March). Financial Sector FDI in Asia: Brief Overview. Bank of Japan Journal.

Economic Commission for Africa. African Trade Policy Centre. (2005, September). Foreign Direct Investment in Africa: Performance, challenges and Responsibilities. Tokyo: Japan.

Fujita, M. (2007). A Critical Assessment of FDI data and Policy Implications. Transnational Corporations, 17(2).

Fung, K. C., \& et al. (2002). Foreign Direct Investment in China: Policy, Trend and Impact. International Conference on China's Economy in the $21^{\text {st }}$ Century, Hong Kong, China. 
Gerardo, M. G., \& et al. (2007). Labour Rights and Free Trade Zones in Mozambique and Namibia: A Crippling Cocktail. Universidade Eduardo Mondlane, Maputo, Mozambique.

Goodspeed, T., \& et al. (2006). Are other Government Policies more Important than Taxation in Attracting FDI? Georgia State University, Andrew Young School of Policy Study, Atlanta.

Kebonang, Z., \& Mosweu, S. (2004). NEPAD and the Challenges of Attracting Foreign Direct Investments in Africa. [Online] Available: www.jsd-africa.com

Kind, H. J., \& et al. (2001). The Role of FDI in Economic Development. Foundation for Research in Economic and Business Administration. Bergen. Working paper No. 62/01.

Lim, S -H. (2007). How investment promotion affects attracting foreign direct investment: Analytical argument and empirical analyses. International Business Review, 17(2008), 39-53. ScienceDirect, Seoul.

Moosa, I. A. (2005). The determinants of foreign direct investment: an extreme bounds analysis. Department of economics and finance, la Trobe University. J. of multi.fin.manag, 16(2006), 199-211, Melbourne.

Mwilima. N. (2003). Foreign Direct Investment in Africa. Labor Resource and Research Institute. Social Observatory Pilot Project - final Draft Report - FDI.

Nordas. H.K., \& et al. (2000). Mozambique - a sub-Saharan African NIC? Chr. Mishelsen Institute development studies and human rights. Bergen.

OECD, \& OCDE. (2000/4). Main Determinants and Impacts of Foreign Direct Investments on China's Economy. Working papers on International Investments. China.

Pretorius, L. G., \& et al. (2005). The Political Economy of South African Foreign Direct Investment in Mozambique: A case Study of Mozal and its Implications for Development in Mozambique and Southern Africa. University of the Western Cape. Faculty of Economics and Management. Phd Paper.

Qiang Zhou. (2008). The myths of China's Economic Growth-Open Trade, Factor mobility and Political Stability. Columbia University. Foxit Software company.

Ramkishen, S. R., \& Rabin, H. (2009). Understanding Bilateral Foreign Direct Investment Flows in Emerging Asia. Institute of South Asian Studies, University of Singapore. ISAS Insight No 81.

Shaukat A., \& Wei. G. (2005). Determinants of FDI in China. Journal of global Business and Technology, I(2), UK.

Sun., \& et al. (2002). Determinants of foreign direct investment across China. Journal of international money and finance, 21(2002), 79-103. Singapore.

Tseng, W., \& et al. (2002). Foreign Direct Investment in China: Some Lessons for other countries. International Monetary Fund. Asian and Pacific Department. Delhi, India.

United Nations Conference on Trade and Development. (UNCTAD). (2002). Trade and Development Report (New York and Geneva: United Nations).

United Nations, ECLAC. (2006). Foreign Investment in Latin America and the Caribbean. Santiago, Chile.

Wei, G., \& Shaukat A. (2005). Determinants of FDI in China. Journal of Global Business and Technology, 1(2).

[Online] Available: http://www.economywatch.com/foreign-direct-investment/determinants.html

[Online] Available: http://www.bancomoc.mz/Files/CDI/RA_2009pt.pdf

[Online] Available: http://www.fdi.gov.cn/pub/FDI_EN/Statistics/default.htm

\section{List of Abbreviations}

FDI

GNP

ERP

IMF

UNCTAD

TNC's
Foreign Direct Investments

Gross National Product

Economic Recovery Program

International Monetary Fund

United Nations Conference on Trade and Development

Transnational Corporations 
ECLAC

SSA

CUTS

GDP

IPA

CJV

EJV

SEZ's

WFOEs

CPI

OECD

CGFS

CEE

MNEs

Economic Commission for Latin America and the Caribbean

Sub-Saharan Africa

Consumer Unity \& Trust Society

Gross domestic Product

Investments Promotion Agency

Contractual Joint Ventures

Equity Joint Ventures

Special Economic Zones

Wholly Foreign Owned Enterprises

Centro de Promoçao de Investimentos

Organization for Economic Co-operation and Development

Committee on the Global Finance System

Central and Eastern Europe

Multi-Nationals Enterprises

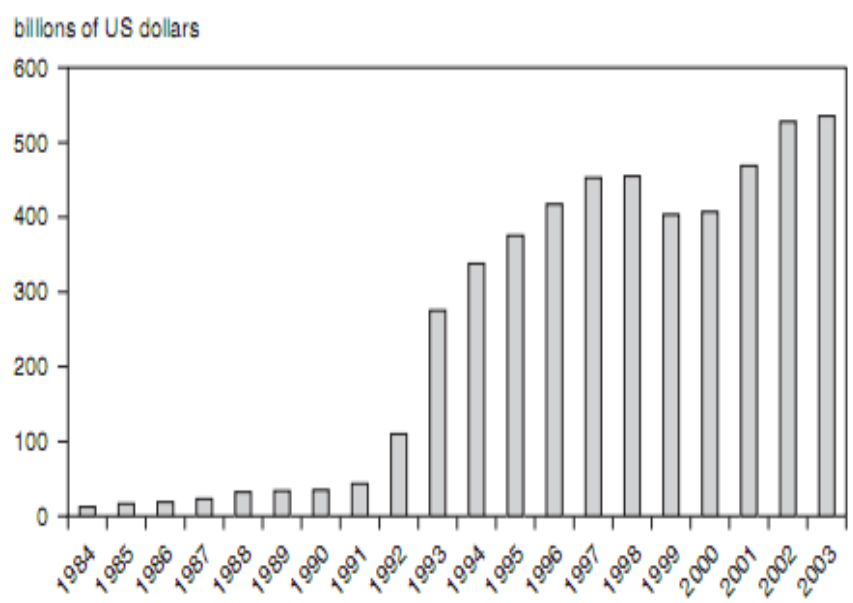

Source: China Ministry of Commerce.

Chart 1. FDI in China, 1984-2003

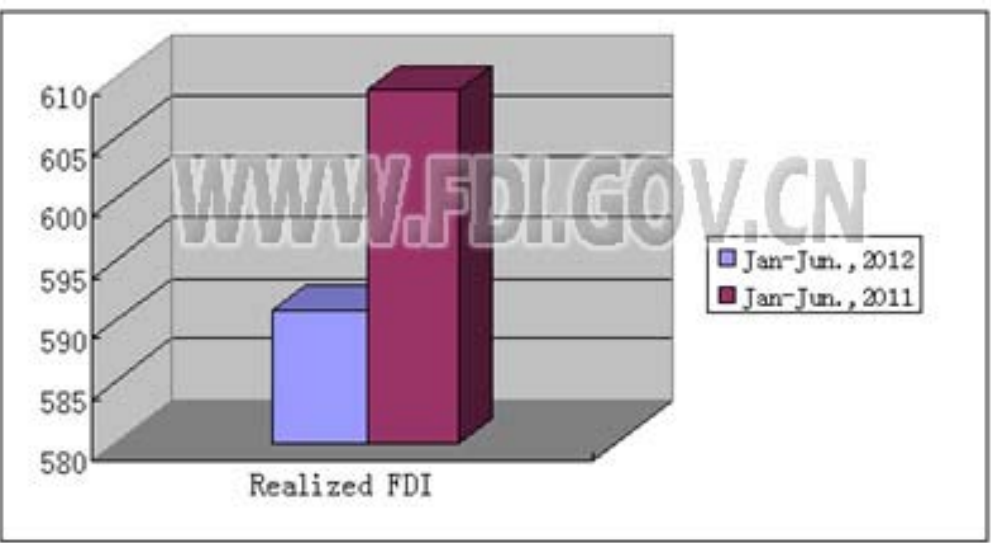

Chart 2. Foreign invested enterprises in China

Source: Ministry of Commerce People’s Republic of China 


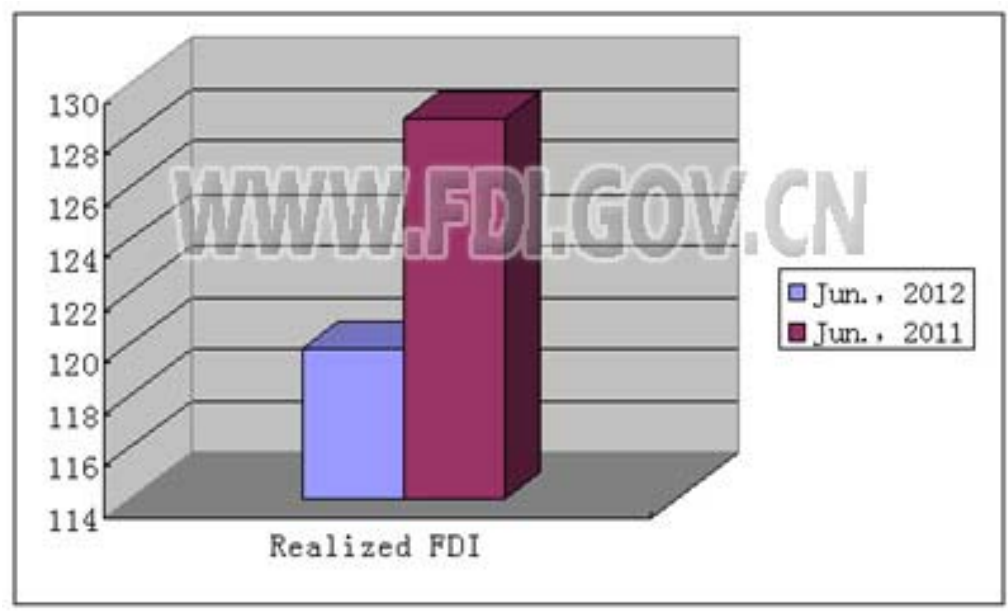

Chart 3. Realized FDI within 6 months

Source: Ministry of Commerce People’s Republic of China

FDI by sector, in 2008

\begin{tabular}{lr}
\hline Nanufacturing industry & $44 \%$ \\
\hline Agriculture, Livestock, Hunting e Forestry & $32 \%$ \\
\hline Extractive industry & $10 \%$ \\
\hline Whole and retail trade and others & $5 \%$ \\
\hline Financial activities & $4 \%$ \\
\hline Hotels and restaurants & $2 \%$ \\
\hline Construction & $2 \%$ \\
\hline Others & $1 \%$ \\
\hline Source: Bank of Mozambloue. &
\end{tabular}

Forelgn Direct Investment in Mozamblque 2002-2008 (USD MIIIION).

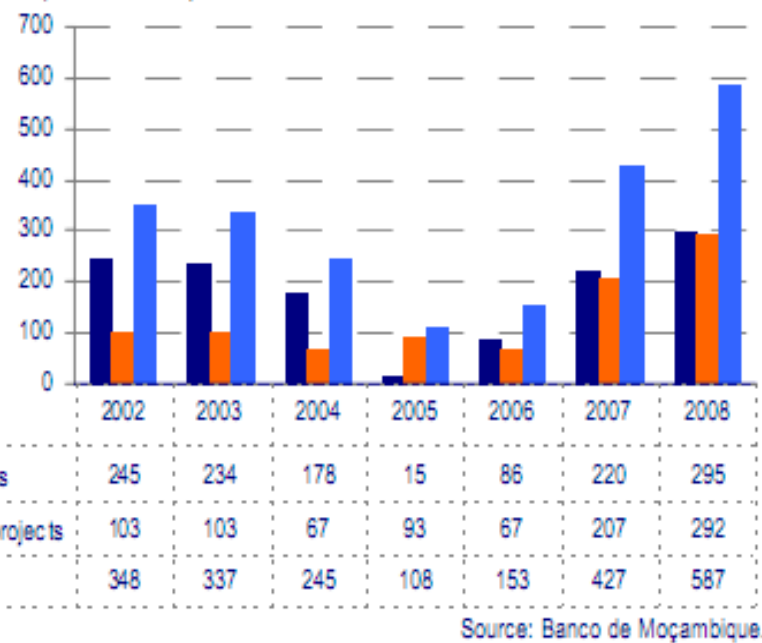

Main investors were South Africa (for the third consecutive year). Switzerland, Brazil, Netherlands, Mauritius, Austria and India

Chart 4. Represents the investments distributed by sectors in 2008 
Ten major Investors In Mozambique. 2008 (USD MIIIlon).

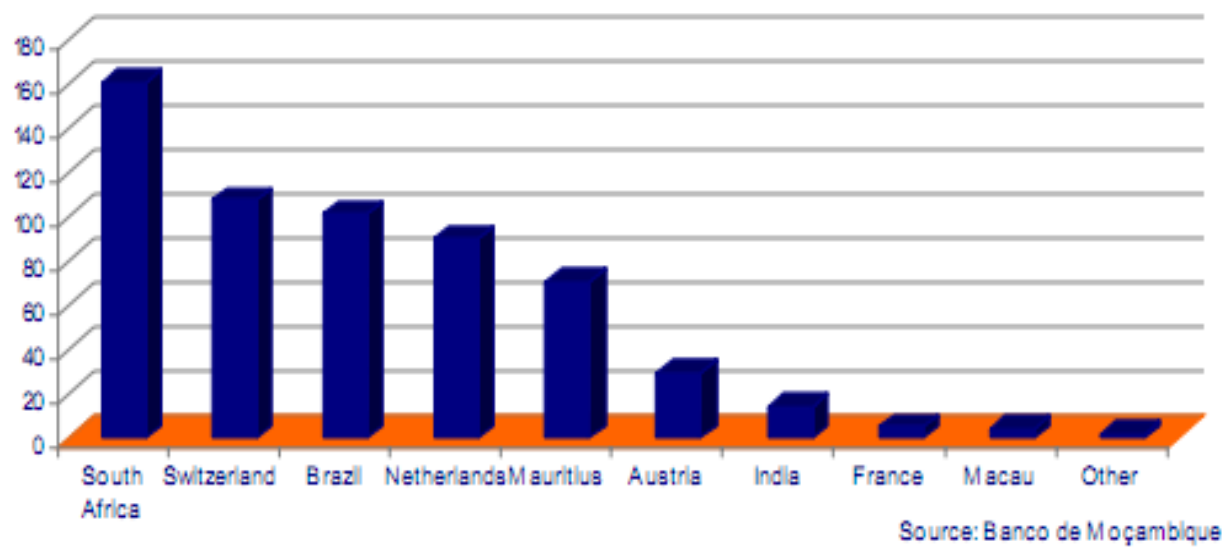

Chart 5. Countries investing in Mozambique

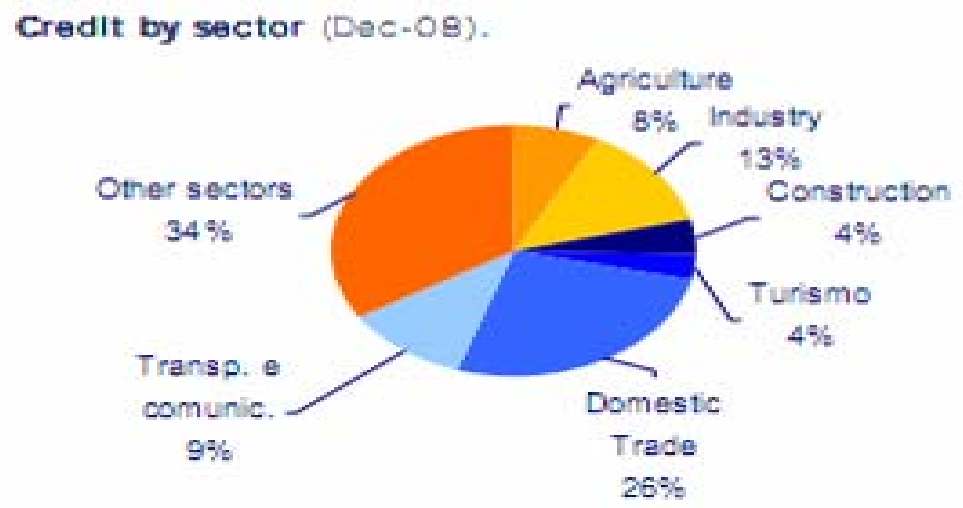

Source: Banco de Moçambique

Figure 1. Contribution to Mozambique GDP 